\title{
The Effect of Service Quality on Loyalty of Tri Indonesia Cellular Operator
}

\author{
Muhammad Yusuf Fadillah" ${ }^{\# 1}$, Indira Rachmawati ${ }^{* 2}$ \\ \#, * School of Economics and Business, Telkom University \\ Jl.Telekomunikasi Terusan Buah Batu, Bandung 40257
}

\begin{abstract}
This research was conducted to explain service quality as the main factor that determines the level of customer satisfaction in service quality dimensions. In addition, this research investigates whether the level of service quality provided by Tri Indonesia can increase customer satisfaction in using Tri cellular operator. The respondents of this research were Tri cellular operator users in Indonesia which were divided into three regions with a total sample of 400 respondents and conducted using non-probability sampling technique. Data processing tools was PLS-SEM and the findings indicated that there was a significant effect between service quality and loyalty. Moreover, this research can be used as a competitive strategy with business competitors, and can measure the quality performance provided by companies by looking at the level of consumer loyalty.
\end{abstract}

Keywords - Cellular Operator, Indonesia, Loyalty, Service Quality, Tri.

\section{INTRODUCTION}

PT Hutchison 3 Indonesia (H3I)is a cellular operator providing telecommunications services with a national license with a 2G, 3G and 4G LTE GSM network in Indonesia. PT H3I launched a service provider product called "3" (Tri) which was established in 2007. Tri Indonesia is committed to providing competent and affordable telephone, SMS and internet-based communication services because it has spread to 227 cities in Indonesia. The high demand for smart phone usage has caused many cellular operator products to cause fluctuating conditions in the community regarding the selection of providers to be used because customers do not only have one card, but they have two kinds of cards that are used from one smart phone ${ }^{[27]}$.

In accordance with the condition of the use of Tri cellular operator services in Indonesia, in the period of 4 years during 2014-2018, Tri Indonesia tended to not have many users compared to competitors. In 2014 Tri Indonesia cellular service operators had 50,160,000 users, in 2015 there were 55,500,000 users, in 2016 there were 55,500,000 users, in 2017 there were 63,617,547 users, and in 2018 there was a significant decrease to $32,315,440$ users. This is when totaled as many as 257,092,987 users and get the fourth position out of the five total user users in Indonesia within 4 years ${ }^{[10][25][27][29]}$.

This research was conducted using an outer model evaluation method whose purpose is to find out the performance of the research instrument and the inner model evaluation using $R^{2}$ as a measure of the degree of variation in a change from a variable independent of the dependent variable. The purpose of this study is to show how much impact Service Quality has on customer loyalty.

\section{LITERATURE REVIEW}

Marketing is a method of creating relationships with customers that can be attempted with the method of delivering products to customers themselves. Aspects obtained in marketing include pricing, determining product choices, distribution, and promotion. Marketing activities must be driven by capabilities gained in an organization, successful marketing activities can realize organizational goals ${ }^{[14][26]}$. Service is a non-product service that has benefits that can be offered to others and is intangible ${ }^{[14][19]}$.

Service quality is an activity in serving customers with, paying attention to important aspects such as high quality, achieving high market share, can increase company profits. While customer service is an activity in marketing products / services. Therefore, service quality is an indicator of the company in carrying out services to customers by its employees. Services determined by service quality will be of higher quality and in accordance with the choice of the consumers ${ }^{[23]}$. 
Measuring power in service quality is determined by various multi-item scales that have been set up in order to know customer perceptions and expectations, such as tangible, empathy, responsiveness, reliability, assurance $^{[26]}$.

Loyalty is a strength of the relationship of individual attitudes in relation to repetition and loyalty, where the individual is committed to being a customer in a buying and selling activity that occurs repeatedly and consistently ${ }^{[18]}$.

\section{A. Hypothesis}

Hypothesis is an unexpected relationship of two variables that are tested through empirical so that it can be formulated in a proposition ${ }^{[9]}$.

$\mathrm{H}_{1}$ : Tangibles has a positive effect on loyalty

$\mathrm{H}_{2}$ : Reliability has a positive effect on loyalty

$\mathrm{H}_{3}$ : Responsiveness has a positive effect on loyalty

$\mathrm{H}_{4}$ : Assurance has a positive effect on loyalty

$\mathrm{H}_{5}$ : Empathy has a positive effect onloyalty

\section{B. Population and Sampling}

Population is a whole with a number that includes objects and has certain criteria that have been determined in a study in order to create results and conclusions ${ }^{[21]}$. This study looked for populations with the criteria of Tri Indonesia cellular operator users and who had visited / contacted outlets / call centers.

The sampling method is a way to get selected samples by random sampling ${ }^{[6]}$. The formula used is the Slovin formula and produces a total of 400 respondents. This study will use a regional division, namely the West Indonesia Region at 338 samples, the Central Indonesia Region at 64 samples, and the Eastern Indonesia Region at 8 samples.

\section{METHOD}

The research methodology used in this study is quantitative methods. Quantitative research is a form of scientific research by examining a problem that relates a phenomenon to the intended variable or based on a causal relationship. The type of research investigation is to use the causal type to find out the cause of the problem based on the time of this research using a cross section method, which is a type of survey that examines an object between one or more variables ${ }^{[11][12][21]}$.

\section{A. Test Validity and Reliability}

Validity test is useful for testing selected research instruments in order to determine the measurement of the level of accuracy in measuring data that should be measured or not ${ }^{[7]}$.

Reliability test is a useful measurement tool to determine the consistency of the measurement results. This measurement works by comparing the results of one study with another will show the same thing or not. The reliability test of instrument items in this study is in the form of a scale with the Cronbach Alpha ${ }^{[22]}$.

\section{B. Partial Least Square}

Partial least square Is a technique in multivariate statistical analysis that compares multiple dependent variables at once. The purpose of this PLS is to be able to predict the effect of variable X against Y and see the theoretical relationship of the two variables ${ }^{[1]}$.

Outer model is an evaluation activity that is useful to find out how much the performance of research instruments. This research can be done if it has carried out the verification stage of the relational and causal relationships of the model to be predicted ${ }^{[1]}$.

The inner model is the evaluation activity using $\mathrm{R}^{2}$ in the dependent construct. The trick is to test the significance of the value of the path coefficient of each path contained in the structural model. The value of $R^{2}$ is useful as a measure of the degree of variation in the change of an independent variable to the dependent variable. If the $\mathrm{R}^{2}$ value is higher, it means the better the prediction model of the study ${ }^{[1]}$. 


\section{RESULTS}

The Hypotheses were tested by PLS-SEMusing Smart PLS 3.0. and the results areas follows:

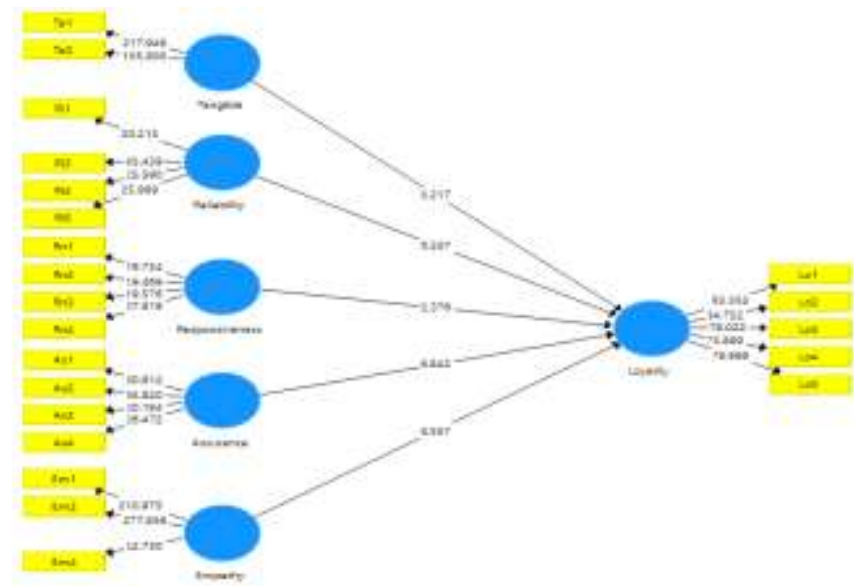

\section{A. Outer Model}

Fig 1.Model Partial Least Square (PLS)

Outer loading or loading factors can test convergent validity. An indicator is declared to meet convergent validity if the outer loading value is more than 0.7 . Here are the results of the calculation of the outer loading of each indicator variable examined.

Tabel 1. Outer Loading

\begin{tabular}{|c|c|c|}
\hline Variabel & Indikator & Outer Loading \\
\hline \multirow{4}{*}{ Assurance (X1) } & As1 & 0.864 \\
\cline { 2 - 3 } & As2 & 0.851 \\
\cline { 2 - 3 } & As3 & 0.710 \\
\hline \multirow{4}{*}{ Empathy (X2) } & As4 & 0.731 \\
\cline { 2 - 3 } & Em1 & 0.964 \\
\cline { 2 - 3 } & Em2 & 0.969 \\
\hline Loyality (Y1) & Em4 & 0.878 \\
\cline { 2 - 3 } & Lo1 & 0.908 \\
\cline { 2 - 3 } & Lo2 & 0.912 \\
\cline { 2 - 3 } & Lo3 & 0.902 \\
\cline { 2 - 3 } Reliability (X3) & Lo4 & 0.898 \\
\cline { 2 - 3 } & Lo5 & 0.897 \\
\cline { 2 - 3 } & Ri1 & 0.733 \\
\cline { 2 - 3 } & Ri3 & 0.808 \\
\hline \multirow{4}{*}{ Responsiveness } & Ri4 & 0.786 \\
\cline { 2 - 3 } (X4) & Ri5 & 0.762 \\
\cline { 2 - 3 } & Rn1 & 0.748 \\
\cline { 2 - 3 } & Rn2 & 0.752 \\
\cline { 2 - 3 } & Rn3 & 0,746 \\
\hline Tangible (X5) & Rn4 & 0.753 \\
\cline { 2 - 3 } & Ta1 & 0.965 \\
\hline & Ta2 & 0.960 \\
\hline
\end{tabular}

According to the data in Table 1 and Figure 1, it can be seen that each indicator of the research variable shows an outer loading value of more than 0.7 . So that means that all indicators in this study are valid used in the study. The next step is to observe the results of outer loading and the results of the discriminant convergent can be identified through the average variant extracted (AVE) value of each indicator. The requirement for AVE is 0.5 to be said to be valid.

Tabel 2. Average Variant Extrancted (AVE)

\begin{tabular}{|l|c|}
\hline \multicolumn{1}{|c|}{ Variable } & AVE \\
\hline Assurance & 0.627 \\
\hline Empathy & 0.879 \\
\hline Loyalty & 0.816 \\
\hline Reliabilty & 0.597 \\
\hline Responsiveness & 0.562 \\
\hline Tangible & 0.926 \\
\hline
\end{tabular}


Based on Table 2, AVE value of each indicator variable is assurance at 0.627, Empathy 0.879, Loyalty 0.816, Reliability 0.597, Responsiveness 0.562 , and Tangible 0.926. According to these data, it can be concluded that the average value produced is more than 0.5 . This means that the research instruments distributed are valid. Furthermore as seen in Table 3, composite reliability were considered good.

Tabel 3. Composite Reliability

\begin{tabular}{|l|c|}
\hline \multicolumn{1}{|c|}{ Variable } & $\begin{array}{c}\text { Composite } \\
\text { Reliability }\end{array}$ \\
\hline Assurance & 0.870 \\
\hline Empathy & 0.956 \\
\hline Loyalty & 0.957 \\
\hline Reliabilty & 0.856 \\
\hline Responsiveness & 0.837 \\
\hline Tangible & 0.962 \\
\hline
\end{tabular}

Composite Reliability that has been generated from each of the indicators - this research gets results of Assurance 0.870, Empathy 0.956, loyalty 0.957, Reliability 0.856, Responsiveness 0.837 , Tangible 0.962 resulting in an average number of more than 0.6 , so it has a high level of reliability.Cronbach alpha is a reliability test to strengthen the value of composite reliability. In accordance with Table 4 , it can be seen if the variable can be declared reliable if it has met the requirements of Cronbach Alpha with a Cronbach Alpha value of more than 0.7 .

Tabel 4. Cronbach Alpha

\begin{tabular}{|l|c|}
\hline \multicolumn{1}{|c|}{ Variable } & Cronbach alpha \\
\hline Assurance & 0.803 \\
\hline Empathy & 0.931 \\
\hline Loyalty & 0.944 \\
\hline Reliabilty & 0.788 \\
\hline Responsiveness & 0.752 \\
\hline Tangible & 0.921 \\
\hline
\end{tabular}

Data from the Table 4 shows the Assurance level of 0.803, Emphaty 0.931, Loyalty 0.944, Reliability 0.788, Responsiveness 0.752 , and Tangible 0.921. If it is concluded that the average value generated is more than 0.7, it can be concluded that all questions distributed are valid.To analyze the results of discriminant validity, you can use the value of cross loading in each of the biggest indicators when compared with other variables. The following results from cross loading in each indicator can be seen in Table 5 .

Tabel 5 : Cross Loading

\begin{tabular}{|l|l|l|l|l|l|l|}
\hline $\begin{array}{l}\text { Indi- } \\
\text { cator }\end{array}$ & $\begin{array}{l}\text { Assur } \\
\text { ance }\end{array}$ & $\begin{array}{l}\text { Em- } \\
\text { pathy }\end{array}$ & $\begin{array}{l}\text { Loy- } \\
\text { alty }\end{array}$ & $\begin{array}{l}\text { Reli- } \\
\text { abil- } \\
\text { ity }\end{array}$ & $\begin{array}{l}\text { Respon } \\
\text { siveness }\end{array}$ & $\begin{array}{l}\text { Tan- } \\
\text { gible }\end{array}$ \\
\hline As1 & 0.864 & 0.557 & 0.709 & 0.540 & 0,523 & 0.575 \\
\hline As2 & 0.851 & 0.518 & 0.628 & 0.487 & 0.483 & 0.514 \\
\hline As3 & 0.710 & 0.410 & 0.451 & 0.556 & 0.566 & 0.338 \\
\hline As4 & 0.731 & 0.502 & 0.503 & 0.637 & 0.639 & 0.407 \\
\hline Em1 & 0.632 & 0.964 & 0.788 & 0.644 & 0.724 & 0.555 \\
\hline Em2 & 0.639 & 0.969 & 0.780 & 0.661 & 0.720 & 0.560 \\
\hline Em4 & 0.488 & 0.878 & 0.618 & 0.541 & 0.614 & 0.408 \\
\hline Lo1 & 0.700 & 0.643 & 0.908 & 0.665 & 0.558 & 0.551 \\
\hline Lo2 & 0.670 & 0.695 & 0.912 & 0.665 & 0.611 & 0.546 \\
\hline Lo3 & 0.676 & 0.691 & 0.902 & 0.654 & 0.606 & 0.520 \\
\hline Lo4 & 0.617 & 0,699 & 0.898 & 0.684 & 0.615 & 0.514 \\
\hline Lo5 & 0.669 & 0.803 & 0.897 & 0.657 & 0.673 & 0.572 \\
\hline Ri1 & 0.454 & 0.320 & 0.400 & 0.733 & 0.511 & 0.327 \\
\hline Ri3 & 0.623 & 0.700 & 0.795 & 0.808 & 0.631 & 0.526 \\
\hline Ri4 & 0,531 & 0.409 & 0.448 & 0.786 & 0.622 & 0.351 \\
\hline Ri5 & 0.458 & 0.464 & 0.465 & 0.762 & 0.633 & 0.346 \\
\hline Rn1 & 0.468 & 0.429 & 0.387 & 0.617 & 0.748 & 0.323 \\
\hline Rn2 & 0.451 & 0.399 & 0.418 & 0.538 & 0.752 & 0.353 \\
\hline Rn3 & 0.564 & 0.420 & 0.443 & 0.616 & 0.746 & 0.433 \\
\hline & & & & & & \\
\hline
\end{tabular}




\begin{tabular}{|l|l|l|l|l|l|l|}
\hline Rn4 & 0.540 & 0.801 & 0.679 & 0.574 & 0.753 & 0.486 \\
\hline Ta1 & 0.579 & 0.532 & 0.593 & 0.518 & 0.522 & 0.965 \\
\hline Ta2 & 0.561 & 0.522 & 0.560 & 0.499 & 0.535 & 0.960 \\
\hline
\end{tabular}

Based on the data in table 5, the latency variables Assurance, Empathy, Loyalty, Reliability, Responsiveness, and Tangible from each of each indicator can produce a value of more than 0.7 higher than the other latent variables. The conclusion is that these variables are better than the other latent variables.

\section{B. Inner Model}

Tabel 6. R-Square

\begin{tabular}{|l|c|}
\hline Indicator & R-square \\
\hline Loyalty & 0.749 \\
\hline
\end{tabular}

In accordance with Table 6, R-square value of 0.749 is obtained. This means that the latent variable of Service Quality can be explained well by Loyalty of $74.9 \%$, while $25.1 \%$ is explained by other variables that are outside of what has been studied. The results of data processing as a whole can be used to answer the research hypothesis.

The hypotheses test was done by looking at the results of the T-statistics and the value of the P-value. The research hypothesis can be accepted if the p-value shows less than 0.5 . The following are the results of the research hypothesis test which can be seen in Table 7.

Tabel 7. Hyphoteses Testing

\begin{tabular}{|c|c|c|c|c|}
\hline Hypothesis & & $\begin{array}{c}\mathrm{T}- \\
\text { Statistics }\end{array}$ & $\begin{array}{c}\text { P- } \\
\text { Values }\end{array}$ & Results \\
\hline H1 & $\begin{array}{l}\text { Assurance - } \\
>\text { Loyality }\end{array}$ & 6.842 & 0.000 & Supported \\
\hline H2 & $\begin{array}{c}\text { Emphaty -> } \\
\text { Loyality }\end{array}$ & 9.557 & 0.000 & Supported \\
\hline H3 & $\begin{array}{c}\text { Reliability - } \\
>\text { Loyality }\end{array}$ & 6.337 & 0.000 & Supported \\
\hline H4 & $\begin{array}{l}\text { Respon- } \\
\text { siveness -> } \\
\text { Loyality }\end{array}$ & 2.376 & 0.018 & Supported \\
\hline H5 & $\begin{array}{c}\text { Tangible -> } \\
\text { Loyality }\end{array}$ & 3.217 & 0.001 & Supported \\
\hline
\end{tabular}

Table 7 shows that the five hypotheses in this study are acceptable, because each of the effects tested gets a value below 0.5 . It can be concluded that the relationship between Service quality on Loyalty has a significant effect.

\section{Discussion}

Based on the findings that has been done to answer the hypothesis, it is known from the five hypotheses that all of them are acceptable, for the effect of Assurance, Empathy, and Reliability on Loyalty get results of 0,000 with positive T-statistics and path coefficient of t-statistics of 6.842, 9.557, and 6.337 studies This has supported the research of Sudirman and Atmosphere (2018); Nurhadi and Azis (2018); Dubey and Srivavastava (2016): Agyei and Kilika (2013) that Assurance, Emphaty, and Reliability have positive effects on loyalty with mixed results $^{[20][15][5][2]}$. For tangible hypotheses get a result of 0.001 with a positive T-statistical value and a path coefficient of 3.217. This research is in accordance with the research of Belwan and Ameirah (2018) ${ }^{[4]}$. Tangible has a positive effect even though it has a small $\mathrm{t}$-statistic value because the telecommunications sector is not too concerned with the physical facilities, equipment, and appearance of employees, unlike hospitals or hospitals that should be more concerned with Tangible, the telecommunications sector is more favored by intangible asset services. Responsiveness gets a result of 0.018 with a positive $\mathrm{T}$-statistical value. The path coefficient obtained has the smallest value of 2.337, and this study is in accordance with Dubey and Srivavastava (2016) which is equal to $1.831^{[5] \text {. }}$ 


\section{VI.CONCLUSIONS}

Based on the results of the research and discussion above, it can be concluded that the quality of service consisting of six dimensions of Service Quality as a whole has a significantly positive effect on loyalty. The explanations are as follows: Assurance has a positive effect on loyalty of Tri Indonesia cellular operator users, or the better the insurance; the more loyal consumers are in using Tri Indonesia services. Reliability has a positive effect on the loyalty of Tri Indonesia cellular operator users, or the better the reliability, the more loyal consumers are in using Tri Indonesia services. Empathy has a positive effect on the loyalty of Tri Indonesia cellular operator users, or the better the Empathy; the more loyal consumers are in using Tri Indonesia services. Responsiveness has a significantly positive effect on the loyalty of Tri Indonesia cellular operator users, meanings that the better the Responsiveness, the more loyal consumers are in using Tri Indonesia services. Tangible has a positive effect on the loyalty of Tri Indonesia cellular operator users, meanings that the better Tangible, the more loyal consumers are in using Tri Indonesia services.

\section{REFERENCES}

[1] Abdillah, Willy dan Jogiyanto.2015.Partial Least Square (PLS) Alternatif Structural Equation Modelling (SEM) dalam Penelitian Bisnis. Edisi ke 1. Yogyakarta:ANDI

[2] Agyei dan Kilika (2013). The Relationship Between Service Quality and Customer Loyalty in the Kenyan Mobile Telecomunication Service Industry-Centre For Continuing Education University of Cape Coast. 23(15). 26-35 Retrieved From European Journal of Business and Management.

[3] Balitbangsdm.kominfo. (2018). ARPU Prabayar Seluler (online). Tersedia : https://balitbangsdm.kominfo.go.id/ [1 maret 2019]

[4] Belwal dan Amireh (2018). Service Quality and Attitudinal Loyalty : Consumers' Perception of Two Major Telecomunication Companies In Oman-Faculty of Business School Sohar University.13.197-208 Retrieved From Arab Economic and Business Journal

[5] Dubey dan Srivavastava (2016). Impact of Service Quality on Customer Loyalty- A Study on Telecom Sector in India - Institute of Management Pt Ravishankar Shukla University, 1(18), 45-55. Retrieved From IOSR-JBM

[6] Hartanti, (2017). Stastistika Untuk Analisis Dan Penelitian.Bandung: CV. Pustaka Setia

[7] Hikmawati, F. (2017). Metodologi Penelitian. Depok: PT Raja Grafindo Persada.

[8] Id.techinasia.com. (2018). Jumlah Pengguna Smartphone di Indonesia 2018 [online]. Tersedia : https://id.techinasia.com/jumlahpengguna-smartphone-di-indonesia-2018 [1 maret 2019]

[9] Indiantoro, nur dan Bambang Supomo. 2014. Metodologi Penelitian Bisnis Untuk Akuntansi \& Manajeman. Edisi 1. Cetakan Ke-12. Yogyakarta:BPFE

[10] Indosatooredo.com. Annual Report (Online). Tersedia: https://indosatooredoo.com/id/personal

[11] Indrawan, R., \& Yaniawati, P. (2014). Metofologi Penelitian: Kuantitatif, Kualitatif, dan Campuran untuk Manajemen, Pembangunan, dan Pendidikan (Cetakan Kesatu). Bandung: PT Refika Aditama.

[12] Indrawati, Raman, M., Wai, C. K., Ariyanti, M., Mansur, D. M., Marhaeni, G. A. M. M., Tohir, L. M., Gaffar, M. R., Has, M. N., \& Yuliansyah, S. (2017). Perilaku Konsumen Individu Dalam Mengadopsi Layanan Berbasis Teknologi Informasi dan Komunikasi (Cetakan Kesatu). Bandung: PT Refika Aditama.

[13] Kasmir. (2005). Pemasaran Jasa. Jakarta: Graya Grafindo Persada

[14] Keller, Kotler. (2009). Manajeman Pemasaran Jilid II. Jakarta: Erlangga

[15] Nurhadi dan Azis (2018). Pengaruh Kualitas Pelayanan terhadap Kepercayaan dan Kesetiaan Konsumen - Fakultas Ekonomi Negeri Yogyakarta, 1(14), 89-98. Retrieved From Jurnal economia.

[16] Parasuraman et al. (1998). SERQUAL: A Multiple item Scalefor Measuring Consumer Perceiption of Service Quality. Journal iof Marketing Vol 44

[17] Priansa Juni, Donni. (2017). Pengembangan Strategi dan Model Pembelajaran Inovatif, Krestif, dan Prestatif Dalam Memahami Peserta Didil. Bandung. CV Pustaka

[18] Rusydi, (2017). Customer Exllence. Yogyakarta:Gosyen Publishing 
[19] Stanton, WY dalam buku Deliyanti. (2013). Manajeman pemasaran Modern. Yogyakarta: LaksBang

[20] Sudirman dan Suasana (2018). Pengaruh Kualitas Layanan Online Terhadap Kepuasan, Komitmen dan Loyalitas Nasabah Internet Banking di Kota Denpasar - Program Studi Manajeman, Fakultas Ekonomi dan Bisnis, Universitas Udayana, 1(4), $473-488$. Retrieved From INOBIS:Jurnal Inovasi Bisnis dan Manajeman Indoneisa.

[21] Sujarweni, V. W. (2015). Metofologi Penelitian Bisnis \& Ekonomi. Yogyakarta: PUSTAKABARUPRESS.

[22] Supardi (2017). Statistik Penelitian Pendidikan: Perhitungan, Penyajian, Penjelasan, Penafsiran, dan Penarikan Kesimpulan. Depok: PT RajaGrafindo Persada.

[23] Susanto, Susanti (2015). Manajeman Pemasaran Jasa.Yogyakarta:CAPS

[24] Tekno.kompas. (2018). Adu kecepatan internet operator seluler indonesia siapa juaranya [online]. Tersedia : https://tekno.kompas.com/read/2018/07/26/14180047/adu-kecepatan-internet-operator-seluler-indonesia-siapa-juaranya [1 maret 2019]

[25] Telkomsel.com.(2019).Annual Report (Online). Tersedia : https://www.telkomsel.com/[1 Maret 2019]

[26] Tjiptono, Fandy. (2014). Pemasaran Jasa. Yogyakarta: C.V Andi Offset

[27] Tri.Indonesia. (2019). About Tri (online). Tersedia : https://tri.co.id/AboutTri [1 maret 2019]

[28] Wikipedia. (2019). 3 (telekomunikasi) [online]. Tersedia : https://id.wikipedia.org/wiki/3_(telekomunikasi) [1 maret 2019]

[29] Xl.co.id.(2019).Annual Report (Online). Tersedia : https://www.xl.co.id/id [1 Maret 2019] 